\title{
Science teacher education in Malaysia: challenges and way forward
}

\author{
Siti Nur Diyana Mahmud ${ }^{1}$, Nurfaradilla Mohamad Nasri', Mohd Ali Samsudin² and Lilia Halim*
}

\footnotetext{
* Correspondence: lilia@ukm.edu.my ${ }^{1}$ Faculty of Education, The National University of Malaysia, 43600 UKM, Bangi, Selangor, Malaysia Full list of author information is available at the end of the article
}

\begin{abstract}
This concept paper discussed the development of science teacher education programs in Malaysia. The discussion encompassed the existing policies, practices and issues, arising from the science teacher education. This paper also reviewed some suggestions for the direction in pre-service training and in-service science teacher training. The development of science teacher education is closely related to the development of science education curriculum. The development of the science education curriculum is connected with the socio-economic needs, political demands of the country and the influence of globalization. Science teacher education in Malaysia began with the training provided by British instructors, which was known as British curriculum. British curriculum was adopted in Malaysia after the independence of Malaya in 1957. In the 1980s, the medium of instruction for science teacher training was changed to Malay. Nevertheless, in 2003, pre-service and in-service science teachers were trained to teach Science in English due to the established policy of Science and Mathematics teaching in English. In 2012, the policy of teaching Science and Mathematics in English was terminated. Subsequently, the medium of instruction in Science was reverted to Malay. Today, the science teachers at the secondary school are trained in the universities, whereas the science teachers at the primary school are trained in Institute of Teacher Education. Meanwhile, the objective of the in-service science teacher training is to give the teachers an insight into any changes in the implemented science curriculum. The science teachers are required to conduct teaching integrating Science, Technology, Engineering and Mathematics (STEM). In addition, science teachers in the selected schools are required to teach Science in English under the Dual Language Programs (DLP).
\end{abstract}

Keywords: Science, Technology, Engineering, and Mathematics (STEM) education, Dual Language Programs (DLP), Higher order thinking skills, Needs assessment, Teacher educators

\section{Executive summary}

Kertas konsep ini membincangkan perkembangan program pendidikan guru sains di Malaysia. Perbincangan ini merangkumi dasar, amalan dan isu yang timbul daripada pendidikan guru sains. Kertas ini juga meninjau beberapa cadangan untuk arahan bagi latihan pra-perkhidmatan dan latihan guru sains dalam perkhidmatan. Perkembangan pendidikan guru sains adalah berkait rapat dengan perkembangan kurikulum pendidikan sains. Perkembangan kurikulum pendidikan sains adalah berkaitan dengan keperluan sosio-ekonomi dan tuntutan politik negara. Di samping itu, tuntutan hasil impak globalisasi turut mempengaruhi perkembangan kurikulum pendidikan sains negara.

(c) The Author(s). 2018 Open Access This article is distributed under the terms of the Creative Commons Attribution 4.0 International License (http://creativecommons.org/licenses/by/4.0/), which permits unrestricted use, distribution, and reproduction in any medium, provided you give appropriate credit to the original author(s) and the source, provide a link to the Creative Commons license, and indicate if changes were made. 
Pendidikan Malaysia dilihat sebagai membentuk insan yang holistik dari segi jasmani, emosi, rohani dan intelek serta wadah untuk memupuk perpaduan. Oleh itu, guru Malaysia memainkan peranan utama dalam hasrat ini yang dinyatakan dalam Falsafah Pendidikan Negara Malaysia.

Secara umumya, pendidikan guru sains di Malaysia bermula dengan latihan daripada pengajar British memandangkan kurikulum sains mereka diadaptasi untuk kegunaan Malaysia selepas mencapai kemerdekaan. Pada tahun 1980-an, apabila Bahasa pengantar adalah Bahasa Melayu, Fakulti Pendidikan di Universiti Kebangsaan Malaysia (UKM) adalah fakulti pertama yang telah melatih guru sains untuk mengajar dalam Bahasa Melayu. Satu lagi perkembangan dalam latihan untuk guru sains ialah dasar pengajaran sains dan matematik dalam Bahasa Inggeris ditubuhkan oleh Kementerian Pendidikan Malaysia pada tahun 2003. Dasar pengajaran sains and matematik adalah diajarkan dalam Bahasa Inggeris. Pada masa kini, guru sains yang mengajar di sekolah rendah dan menengah adalah kebanyakannya guru siswazah. Guru sains sekolah rendah adalah dilatih oleh Institut Pendidikan Guru sebagai guru sains am. Manakala guru sains sekolah menengah adalah dilatih oleh pihak universiti berdasarkan standard ilmu pendidikan yang ditetapkan oleh Agensi Kelayakan Malaysia. Bagi latihan dalam perkhidmatan, tujuan utama adalah untuk memberi motivasi kepada guru terhadap sebarang perubahan kurikulum sains yang telah dilaksanakan. Pada masa yang sama, kursus dalam perkhidmatan juga merangkumi guru sains yang mengikuti program pengajian lanjutan seperti pengajian pasca siswazah.

Walaupun latihan untuk guru sains di Malaysia telah melalui beberapa perkembangan yang mantap tetapi isu brekaitan dengan kualiti guru masih dipersoalkan, khususnya pencapaian yang rendah dalam "Trends in International Mathematics and Science Study" (TIMSS) dan "Programme for International Student Assessment" (PISA). Oleh itu Kementerian telah membuat penambahbaikan terhadap aspek kurikulum, strategi pengajaran dan pembelajaran, latihan guru dan pentaksiran di sekolah rendah, hanya menawarkan latihan guru kepada pelajar lulusan Sijil Pelajaran Malaysia (SPM) yang memperoleh keputusan yang tinggi dan menaikkan peratusan menjalankan praktikum sebanyak 40 peratus.

Untuk guru-guru dalam perkhidmatan, latihan kemahiran menerapkan kemahiran berfikir aras tinggi (KBAT) dan kaedah pengajaran berasaskan projek perlu ditekankan dan diperbanyakkan. Namun, melalui kajian lepas, guru-guru dalam perkhidmatan masih memerlukan kursus seperti ini. Pada masa kini, guru-guru sains dikehendaki menjalankan pengajaran dengan mengintegrasikan Sains, Teknologi, Kejuruteraan dan Matematik (STEM) melalui pendekatan inkuiri, pembelajaran berasaskan projek dan pembelajaran berasaskan masalah.

Perkembangan terkini dalam pendidikan sains di Malaysia adalah pengenalan Program Dwibahasa. Dalam Program Dwibahasa, guru sains diminta untuk mengajar subjek sains menggunakan Bahasa Inggeris. Walau bagaimanapun, sekolah, guru, pelajar dan ibubapa diberi pilihan untuk terlibat dalam inisiatif ini dan bergantung kepada keupayaan sekolah, guru dan pelajar. Ada kajian yang menyatakan guru masih memerlukan bantuan dalam pelaksanaan Program Dwibahasa ini. Perubahan terkini dalam kurikulum sains adalah untuk memperkenalkan penggunaan Pembelajaran Bahasa Berbantukan Komputer (PBBK) di Tahap Satu, sekolah rendah dan Tingkatan Satu, sekolah menengah dan dasar yang sama juga memerlukan latihan untuk guru sains yang relevan dan mantap. 
Kesimpulannya, program pendidikan guru sains adalah dinamik selari dengan perubahan pesat dalam sistem pendidikan Negara dan sistem pendidikan sains khususnya. Oleh itu, penilaian kurikulum pendidikan guru sains harus dikaji dan disemak semula bagi meningkatkan kualiti pendidikan guru dan kualiti guru sains masa depan.

\section{Introduction}

Lee (2004) argued that the Malaysian education system is highly centralized. Thus, the development of science teacher education is closely related to the development of the national education system. The structure teacher education programs i.e. pre-service and in-service trainings are also developed based on the need of the educational system, socio-economic, politics of the country and the impact of globalization.

In 1987, the National Philosophy of Education (NPE) in Malaysia was developed and it reads as:

"Education in Malaysia is an ongoing effort towards further developing the potential of individuals in a holistic and integrated manner so as to produce individuals who are intellectual, spiritually, emotionally and physically balanced and harmonious, based on a firm belief in and devotion of God. Such an effort is designed to produce Malaysian citizens who are knowledgeable and competent, who possess high moral standards and who are responsible and capable in achieving a high level of personal well-being and being able to contribute to the betterment of the family, society and nation at large" (Ministry of Education 2013, Page 4).

This NPE has provided a framework for philosophical changes in content and pedagogy in the primary and secondary curriculum. The NPE has implications for teacher education programs, namely on the recruitment, content and method of teacher trainings. Based on the NPE, Malaysian science teachers are not only able to inculcate an understanding of science content, science process skills and positive attitudes towards science, but also able to inculcate ethics, moral values, and foster unity among students of various ethnic groups.

The recent development in global science education, namely the STEM education, has also influenced the landscape of science education in Malaysia. In particular, the national science curriculum has been revised to accommodate the philosophy of the STEM education, as envisioned by the Ministry of Education (MOE). The STEM education is viewed as: (a) STEM field which covers traditional disciplines such as Physics, and contemporary fields such as Bio-Chemistry; (b) STEM stream- enrollment of students in stream of their choice at the upper secondary level; and (c) STEM approach which is pedagogical approach that emphasises on students' activities solving real-world problems (MOE 2016). Thus, the nature and structure of the science teacher education in Malaysia are inevitably affected.

\section{Brief historical overview of science teacher education in Malaysia}

According to Halim and Meerah (2016), science teaching began in Malaysia in 1937. After the independence of Malaya in 1957, science education was given a special place in the educational policy due to several reasons. First, before the independence, Science for all was not possible due to the lack of adequate equipment and qualified science teachers. Second, Science is considered as an area of the curriculum that most likely to provide the supply of 
scientific and technical manpower for the economic development of the country. Lee (2004) observed that teachers of low academic qualification were recruited and given parttime training during school holidays at teacher training colleges to ease the acute shortage of school teachers at the primary schools. Meanwhile, the graduate teachers were engaged from UK and India to teach at the secondary schools. In science education, the Scottish Integrated Science Syllabus for lower secondary school, the Nuffield Secondary School Science Curriculum, and the Nuffield O- Level pure Science Syllabus were implemented respectively for non-science and pure science streams at upper secondary level from 1968 to 1981.

Lee (2004) further reviewed the teacher education in Malaysia and described that the number of teacher training colleges had increased in the 1980s. The faculty or school education that played the role of training the graduate teachers for secondary schools had begun to develop. Nonetheless, Sumintono (2015) argued that there was still a shortage of a large number of teachers. Thus, the science teachers from Indonesia were engaged to teach Science in various schools. In the mid-1980s, the medium of instruction was switched from English to Malay at primary and secondary schools. The Faculty of Education The National University of Malaysia, was the first faculty to train science teachers to teach science subjects in Malay.

In 2003, there was another major development in Science teacher education in Malaysia. It was when the Malaysian government decided that Science and Mathematics to be taught in English at all levels in primary and secondary education, which was known as PPSMI (Pengajaran dan Pembelajaran Sains dan Matematik Dalam Bahasa Inggeris) (Sumintono 2015). The political leaders argued that, for Malaysians to leverage on the outcome of the scientific knowledge and know -how, which is often conveyed in English (Halim and Meerah 2016), Science and Mathematics educations need to be taught in English.

As a result, the content and method of Science teacher preparation program were revised. Educational studies, science content and methods courses were taught in English. Various related activities were conducted for in-service programs. The activities included offering short-term in-service training courses to enhance the linguistic skills and the confidence level of science teachers; providing science teachers with preprepared multimedia teaching course to facilitate the teaching; and learning of science through the integration of Information Communication Technology (ICT). Moreover, Science and Mathematics teachers were given incentives for the implementation of the policy (Sumintono 2015; Halim and Meerah 2016; Idris et al. 2007).

As the national long-term strategy is to improve the quality of teaching, thus the MOE aims to have $100 \%$ graduate teaching force at all secondary schools and primary schools. To meet this challenge, various collaborations between teacher training colleges and local universities were organised for increasing the number of graduate science teachers (Lee 2004). For the purpose of meeting the demand for graduate science teachers at the primary schools, in 2005, all teacher training colleges were upgraded to teacher education institutes that led to the institutes conferring degrees. Thus, the teacher education programs shift its focus to awarding degrees instead of the diploma in teaching.

\section{Current policies, practices and emerging issues in Malaysia}

The historical development of teacher education in Malaysia has contributed to two public institutions i.e. the universities and the Institute of Teacher Education (ITE), 
which offer teacher training programs in Malaysia. ITE is controlled by the MOE through its Teacher Education Division (TED) to train science teachers for the primary schools. Today, there are 27 ITE interspersed throughout different states in Malaysia.

The curriculum structure of Bachelor of Science Education (Primary) offered by the ITE is more of general science content. It is a common view that the lack of content knowledge on the part of the teachers might influence students' comprehension and the development of inquiry-based science teaching Meanwhile, public universities under the Ministry of Higher Education (MOHE) conduct 4-year Bachelor of Education through the faculties of the universities. Qualified teachers with a teacher education degree from the universities can teach at the secondary schools and matriculation programs. The universities have autonomy in structuring their teacher education curriculum, whereas ITE has a common curriculum controlled by TED. Nevertheless, the structure of the curriculum is framed by standard curriculum set by the Malaysian Qualification Agency. The five components for teacher education, include (a) the educational component; (b) the professional practice component; (c) the school subject content; (d) the educational electives component; and (e) the educational specialization component. The universities also conduct the Postgraduate Diploma in Education for those candidates who wish to pursue teaching after obtaining a non-educational first degree.

MOE sets up in-service training programs which often serve as the platform to train the teachers for any curriculum reforms. The training is often conducted by using the cascad model. The selected teachers are to be trained by the master trainers. As a result, the selected teachers are expected to conduct training with other teachers at the state and district levels. Another form of in-service course is through the initiative of the teachers, such as short-term in-service training and development program for teachers teaching critical subjects, namely Science, Mathematics, ICT and English, or enrolling into a Master of Education program.

The Malaysian government has been putting efforts to strengthen the quality of both in- service and pre-service teachers. The budget allocations of the Malaysian government have been increased for in-service training programs and teachers' continuous professional development (Jamil et al. 2010). Thus, Malaysia has made a great progress in its initial teacher education after its independence, by providing equal access to schools and achieving educational prominence in the region.

Some educationists argued that the nation's education has shown a noticeable incline (Goh and Blake 2015), as evidenced in the recent low ranking at the PISA and TIMSS. When Malaysia first participated in TIMSS in 1999, the average score of its students was higher than the international average score in both Mathematics and Science. In 2011, the performance of the system slipped below the international average score in both Mathematics and Science, resulting a commensurate drop in ranking. $35 \%$ to $38 \%$ of Malaysian students failed to meet the minimum proficiency levels critically in Mathematics and Science in 2011(MOE 2013). These students were identified to possess a limited mastery of basic Mathematical and Scientific concepts. The results from PISA 2009 were also discouraging. Malaysia was placed in the bottom-third, ranking 55 out of 74 participating countries, below the international and the Othe rganisation for Economic Cooperation and Development (OECD) average. Almost $60 \%$ of the 15-year-old Malaysian students who participated in PISA failed to meet the minimum proficiency level in Mathematics. 
As the TIMSS and PISA international assessments have demonstrated, Malaysian students struggle with higher-order thinking skills.

Questions have been raised as to whether teacher education in Malaysia is able to prepare the teachers and students for the demands and challenges of the evolving global landscape. The MOE has set up a goal for Malaysia to rise to the top-third of system in TIMSS and PISA (MOE 2013). One of the actions has been taken by MOE to achieve this goal, is to revamp the ITE for pre-service teacher education. The MOE will review the current pre-service training curriculum to ensure the teachers are adequately prepared to teach the higher-order thinking skills desired of Malaysia's students. This will include increasing the percentage of time spent on practicum training to $40 \%$ across all programs.

Furthermore, the MOE emphasizes on continuous professional development. MOE also recognizes the teachers who may require assistance in meeting new competencies, such as teaching the students the higher-order thinking skill. Nevertheless, according to a study conducted by Che Seman et al. (2017), the teaching and learning in Malaysia were still monopolized by low-level thinking instead of higher order thinking. In addition, the findings from Kassim and Zakaria (2015) showed that the teachers had difficulties in constructing higher order thinking questions for students' assessment. Moreover, a study conducted by Hashim (2003) found that the courses or exercises related to this high-level thinking skill were not being introduced to teachers during teacher training and service. The teachers are not given enough exposure to teaching methods and pedagogy of high-level thinking skills. This proves that there is a problem that needs to be studied for the good of the Malaysian educational institution.

In addition, the $\mathrm{MOE}$ also emphasizes on training the science teachers regarding the teaching of higher-order thinking skill. In the latest Malaysia Education Blueprint 2013-2025 (MOE 2013), the MOE focuses on strengthening the quality of STEM education through an enhanced curriculum, testing and training of the science teachers. In 2013, the MOE conducted a diagnostic exercise to identify the gaps in the content knowledge and pedagogical skill among the teachers for STEM subjects, through a combination of testing and lesson observations. As a result, the MOE is able to develop a more tailored approach for professional development. In 2014, the MOE rolled-out School Improvement Specialist Coaches (SISC+) for Science subject.

In 2016, 300 primary and secondary schools were selected for the DLP. The main purpose of DLP is to provide the opportunity for students to use either English or Malay in Science, and Mathematics. This program is expected to enhance students' future employability opportunities. DLP is a continuation of the abolition of the Teaching English and Mathematics in English Program (PPSMI) in 2012. PPSMI was also to ensure both Malay and English reserved without downgrading one of the languages. Unlike PPSMI, DLP works as a voluntary program. DLP involves standard 1 and 4 at primary level and forms 1 at the secondary level. The MOE has set up the English Language Teaching Centre (ELTC) online to help science teachers. Nonetheless, a study was conducted by Unting and Yamat (2017) on teachers' perspective about the DLP. Unting and Yamat (2017) discovered one of the obstacles in implementing the program is the lack of support and guidance to the teachers. Teachers are the implementers and thus play important role in making a program a success. Therefore, teachers should be equipped with ample information and knowledge on the newly introduced program. 
The curriculum revision in 2017 has led to the introduction of computational thinking across the curriculum including science subject, beginning with the students in at primary one in 2018. Wing (2006) argued that apart from reading, writing and arithmetic, every child should learn and master computational thinking. Along the same vein, National Research Council (NRC) (2011), and Barr and Stephenson (2011) reported the need of exposing students to computational thinking as early as possible since these group of students will go into the workforce which is heavily dependent on computers To date, primary teachers are trained on how to integrate computational thinking in the subject matters. As mentioned earlier, training of primary teachers is under the jurisdiction of MOE. Thus, they are able to conduct training in line with the curriculum changes. Teacher training at university level also needs to be alert in response to the rapid changes.

\section{Future directions for teacher education}

Teacher education institutions in Malaysia are facing multiple challenges in preparing skilled science teachers to meet current and future economic as well as political challenges. In this case, teacher education programs are forced to devise a systematic and strategic action plan to: (a) facilitate the emerging role of science teachers in promoting STEM learning; and (b) improve the level of English proficiency among science teacher to teach DLP.; (c) assist science teachers to integrate computational thinking-based science learning in class; (d) equip science teachers with the knowledge, understanding and practices of higher order thinking skills; and (e) upgrade science teachers' ICT skills. This section discusses some of the current and critical issues which are related to the training of science teachers.

(a) Facilitate the emerging role of science teachers in promoting STEM learning

The recent popularity of STEM as an integrated academic discipline, is essential in meeting future social and economic challenges. Such challeges have spawned a worldwide STEM-focused educational movement (Kelley and Knowles 2016). Despite STEM education has long been contemplated in the USA, the concept and idea of the STEM are still new in Malaysia (Bahrum et al. 2017). To keep up with the global trend of STEM, the Malaysian government has initiated Malaysia Education Blueprint (20132025) to increase students' and teachers' interest, attitude and motivation in the STEM, and career awareness related to STEM field.

As reported by many researchers, a majority of the science teachers are struggling in making connections across the STEM disciplines. The lack of an exhaustive understanding of STEM could potentially lead to the feeling of incompetency among science teachers (Ramli and Talib 2017; Roslan et al. 2012; Siew et al. 2015). Ramli and Talib 2017 asserted that most of the science teachers are not confident to integrate STEM in science teaching. As indicated earlier, the MOE has developed and conducted a diagnostic exercise to identify gaps in content knowledge and pedagogical skills among teachers of STEM subjects. Based on the outcome of the diagnostic test, teachers are tailored to the relevant in-service and professional development program.

Despite science teachers are held responsible to teach STEM, they do not receive any comprehensive training on STEM education. Furthermore, the current science teacher 
education program was specifically designed to focus only on specific disciplines, which contradicted the basic principles of STEM teaching (Mustafa et al. 2016). It should be taken into account that STEM education is relatively new in Malaysia and substantial time is required for the science teachers to develop a cohesive understanding to effectively apply the STEM pedagogical approaches in the classroom. Therefore, science teacher education program should be meticulously designed in response to the changing responsibilities and roles of the science teachers. To achieve this goal, it is suggested that science teacher education should expose prospective science teachers to various practical STEM teaching approaches.

Apart from that, Informal Science Education Providers (ISEP) in Malaysia, such as National Planetarium, National Science Centre and museums, play a very important role in helping science teachers to integrate STEM learning among students by offering various experiential and hands-on learning activities. STEM education learning activities, projects and exhibitions conducted by the ISEP focus not only on school students, but also the society at large. For example, ISEP provides training for teachers in integrating technology to motivate students' STEM learning. Moreover, teachers can also enhance their content knowledge as well as pedagogical knowledge by learning and applying the approach provided by the ISEP in their formal science learning process through site-visits.

In addition, science teachers also need to be trained in the most associated pedagogical approach in STEM i.e. inquiry-based teaching, problem-based teaching and project-based teaching. Despite these approaches appear to be common, the adoption, understanding and acquiring the skills to conduct these active-oriented teaching, are still lacking among the Malaysian science teachers (Halim and Meerah 2016). Halim and Meerah (2016) also suggested that the science teacher educators can collaborate with STEM researchers in drawing up the curriculum, namely the content, STEM practice and philosophy in relation to STEM.

(b) Improve the level of English proficiency among the science teachers to teach Dual Language Programs (DLP)

Due to the inadequate understanding of STEM, the science teachers in Malaysia encountered a problem when some teachers were required to teach DLP (Yunus and Sukri 2017). Despite DLP was based on voluntary choice, it is advisable that schools are not solely accountable in making sure that their science teachers get the assistance they need to teach science in English, as increasing bilingual proficiency in Malay and English among students is regarded as one of the national vision (Chan and Abdullah 2015). The shortage of well-trained science teachers to teach Science in English, should not be taken lightly. The incompetency of the science teachers to teach science effectively has an adverse impact on students' learning. A study conducted by Halim et al. (2012) showed that the lack of competency in the language affects the Pedagogical Content Knowledge (PCK) of the science teacher. Therefore, it is important for science teacher education program, especially the teaching methods course encourage the development of PCK in English, in which the repertoire of instructional activities is able to assist students understanding of the science content in English effectively. The studies conducted during the first time the policy of teaching science and mathematics for English in 2013 (Othman and Mohd Saat 2009) stated that pre-service and in-service 
teachers can benefit a course on English for Specific Purposes in their training programs in order to develop them to integrate language and content.

(c) Assist the science teachers to integrate computational thinking-based science learning in class.

The importance of computational thinking was emphasised by the National Council of Research (NCR) (2011). The NCR stated that every individual has to learn and master computational thinking as it forms the foundation of cognitive skills. Calao et al. (2015) reported that students' problem-solving and critical thinking skills have significantly improved when they are exposed to computational thinking. Since this is a new concept for the Malaysian science teacher education program, the initiative is to train teacher educators the concept and method related to computational thinking. As a result, the teacher educators are expected to prepare prospective teachers in supporting students' understanding of computational thinking. Through the application of computational thinking, the students are able to solve both discipline-specific and interdisciplinary problems.

According to Yadav et al. (2017), in preparing the teachers to incorporate computational thinking, the teacher educators need to develop pre-service teachers' knowledge and skills on how to think computationally. For the purpose of developing pre-service teachers' competencies to embed computational thinking in the classroom, the preservice teachers should be able to think computationally. Nonetheless, teachers' ability to think computationally is not sufficient as it does not guarantee the teachers to teach computational thinking effectively. Therefore, the pre-service teachers should also be taught on how to teach their students to think computationally. In general, the teacher educators should equip the pre-service teachers with specific pedagogical content knowledge which enables the teachers to incorporate computational thinking into their curricula and practice in meaningful ways.

(d) Equip the science teachers with the knowledge, understanding and practice of higher order thinking skills

Despite there are pre-service and in-service courses in the programs which are dedicated to teaching thinking, it is more important to provide hands-on activities during the training. The activities include developing higher order questions, creating rubric to assess students' activities, and evaluating the outcomes of a project-based science activity. The training should focus on developing knowledge, understanding, awareness and affinity towards alternative assessments, such as creating portfolio and journal writing.

Most importantly, there should be a periodic needs assessment research on science teachers in terms of knowledge and skills. Such needs assessment would not only inform the development of an effective training program, but also to be able to keep pace with the ever-changing revision of the science curriculum. The cascade training model which is being practiced in Malaysia is good in principle. Nevertheless, in practical terms, not all the teachers have the opportunity to experience in-service training or professional development. Hence, the Ministry of Education should look for other alternatives in making sure that the attempt to effect large-scale change at the classroom level is achieved smoothly and successfully. 
(e) Upgrade science teachers' ICT skills

Due to the rapid growth of today's technology, science teachers should equip themselves with ICT skills to integrate ICT in their teaching process. For instance, the ICT integration in science teaching and learning includes the use of augmented reality, hologram and drones. The drone industry is expected to be a multi-billion industry in the future. Therefore, science teachers should prepare the students to be skilled workforce who are able to apply the drone technology in various fields. Technology integration in science learning has a potential to attract students to study Science. It also supports STEM's main idea of innovation and technology (Barak, 2014). Furthermore, ICT is able to assist the teachers in providing the students with an effective and meaningful learning experience. As a result, ICT can enhance students' engagement (Barak, 2014).

Despite the benefits of ICT integration in education, a study conducted by Sing and Chan (2014) identified that Malaysian teachers are still lack of skill to integrate ICT in their teaching. This situation occurred due to the inadequate training of integrating ICT in teaching (Sing and Chan 2014). In addition, a study conducted by Rosnaini and Mohd Arif (2010) identified that the pre-service teachers were exposed only to the theoretical aspect of ICT instead of its practical aspect during the teaching training. They continued to suggest that in order to improve the teachers' ICT skills, emphasis of practical aspect of the ICT should be integrated into the science teachers' education. Furthermore, the early exposure of pre-service teachers to the ICT integration would convince and better prepared the teachers on the importance of integrating ICT in teaching (Albirini, 2006).

\section{Conclusion}

It is clear that the pattern of science teacher education in Malaysia is closely related to the evolving changes of the science curriculum. The changes are inevitable since Malaysia is a developing country. Thus, it needs to be on par with the rapid changes of the world economiy. Thus, one of the main implications of this concept paper is to determine the continuous professional needs of science teachers. Such a study should be done every three to 5 years to ensure that appropriate continuous professional programs are developed, at both pre-service and in-service levels. Hence, the quality of science teacher education and science teachers is continuously enhanced. In addition, educational practitioners are encouraged to conduct action research, an agenda which has been established by the MOE since 1999. Such agenda should be continuously supported by the ministry. Therefore, the science teachers could expand their knowledge and practice in light of the new demand of the science curriculum. Another main implication of this study is to develop a clearinghouse that posits outcome of the research on science education. Evidence-based science teaching and learning, serves as learning resources, reference or guide towards the enhancement of the quality of science education and the professionalism of science teachers.

Authors' contributions

All authors contributed equally to this article. All authors read and approved the final manuscript. 


\section{Competing interests}

The authors declare that they have no competing interests.

\section{Publisher's Note}

Springer Nature remains neutral with regard to jurisdictional claims in published maps and institutional affiliations.

\section{Author details}

${ }^{1}$ Faculty of Education, The National University of Malaysia, 43600 UKM, Bangi, Selangor, Malaysia. ${ }^{2}$ School of

Educational Studies, University of Science Malaysia, Jalan Sungai Dua, 11700 USM, Penang, Malaysia.

Received: 18 January 2018 Accepted: 8 May 2018

Published online: 15 May 2018

\section{References}

Albirini, A. (2006). Teachers' attitudes toward information and communication technologies. The case of Syrian EFL teachers. Computer \& Education, 47:373-398.

Bahrum, S., Wahid, N., \& Ibrahim, N. (2017). Integration of STEM education in Malaysian and why to STEAM. International Journal of Academic Research in Business and Social Sciences, 7(6), 645-654.

Barak (2014). Closing the gap between attitudes and perceptions about ICTenhanced learning among pre-service STEM teachers. J Sci Educ Technol (2014) 23:1-14.

Barr, V., \& Stephenson, C. (2011). Bringing computational thinking to K-12: What is involved and what is the role of the computer science education community? ACM Inroads, 2(1), 48-54.

Calao, L. A., Moreno-León, J., Correa, H. E., \& Robles, G. (2015). Developing mathematical thinking with scratch: An experiment with 6th-grade students. In Proceedings of the Design for Teaching and Learning in a networked world 10th European conference on technology enhanced learning, Toledo, Spain, sept. 15-18 (pp. 17-27). New York: Springer International Publishing.

Chan, S. H., \& Abdullah, A. N. (2015). Bilingualism in Malaysia: Language education policy and local needs. Pertanika Journal of Social Science and Humanities, 23(s), 55-70.

Che Seman, S., Wan Yusoff, W. M., \& Embong, R. (2017). Teachers challenges in teaching and learning for higher order thinking skills (HOTS) in primary school. International Journal of Asian Social Science, 7(7), 534-545.

Goh, P. S. C., \& Blake, D. (2015). Teacher preparation in Malaysia: Needed changes. Teaching in Higher Education, 20, 469-480. https://doi.org/10.1080/13562517.2015.1020780.

Halim, L., Dahlan, F., Treagust, D. F., \& Chandrasegaran, A. L. (2012). Experiences of teaching the heat energy topic in English as a second language. Science Education International, 23(2), 17-132.

Halim, L., \& Meerah, T. S. (2016). Science education research and practice in Malaysia. In M. H. Chui (Ed.), Science education research and practice in Asia: Challenges and opportunities (pp. 71-93). Singapore: Springer.

Hashim, R. (2003). Malaysian's teachers attitude, competency and practices in the teaching of thinking. International Islamic University Malaysia, 11(1), 27-50.

Idris, N., Cheong, L. S., Nor, N. M., Abdul Razak, A. Z., \& Saad, R. M. (2007). The professional preparation of Malaysian teachers in the implementation of teaching and learning of mathematics and science in English. Eurasia Journal of Mathematics Science and Technology Education, 3(2), 101-110.

Jamil, H., Abd Razak, N., Ahmad, M. Z., \& Issa, J. H. (2010). A study on the policies and practices of teacher education in Malaysia towards producing quality pre-service teachers. In Comparative evidence on the development of initial teacher education policy in the Asia-Pacific region (pp. 15-17).

Kassim, N., \& Zakaria, E. (2015). Integrasi kemahiran berfikir aras tinggi dalam pengajaran dan pembelajaran matematik: Analisis Keperluan Guru. Jurnal Pendidikan Matematik, 3(1), 1-12.

Kelley, T. R., \& Knowles, J. G. (2016). A conceptual framework for integrated STEM education. International Journal of STEM Education, 3(11), 1-11. https://doi.org/10.1186/s40594-016-0046-z.

Lee, M. N. N. (2004). Malaysian teacher education into the new century. In Y. C. Cheng, K. W. Chow, \& M. M. C. Mok (Eds.), Reform of teacher education in the Asia-Pacific in the new millennium: Trends and challenges, Education in the Asia-Pacific region: Issues concerns and prospects, vol 3 (pp. 81-91). Dordrecht: Springer.

Malaysia Ministry of Education. (2013). Malaysia education blueprint 2013-2025. Putrajaya: Ministry of Education.

Ministry of Education Malaysia (MOE). (2016). Implementation guide for science, technology, engineering, and mathematics (STEM) in teaching and learning. Putrajaya: MOE.

Mustafa, N., Ismail, Z., Tasir, Z., \& Said, M. N. H. M. (2016). A meta-analysis of effective strategies for integrated STEM education. Advanced Science Letters, 12, 4225-4229.

National Research Council. (2011). Report of a workshop of pedagogical aspects of computational thinking. Washington, D. C: The National Academies Press.

Othman, J., \& Mohd Saat, R. (2009). Challenges of using English as a medium of instruction: Pre-service science teachers' perspective. The Asia-Pacific Education Researcher, 18(2), 307-316.

Ramli, N. F., \& Talib, O. (2017). Can education institution implement STEM? From Malaysian teachers' view.International Journal of Academic Research in Business and Social Sciences, 7(3), 721-732.

Roslan, S., Sharifah, M. N., \& Thirumalai, V. N. (2012). The burnout phenomenon: Changes in psychosocial profiles of secondary school teachers. Pertanika Journal of Social Science and Humanities, 20(s), 157-174.

Rosnaini, M. and H.I. Mohd Arif, (2010). Impact of training and experience in using ICT on in-service teachers' basic ICT literacy. Malaysian Journal of Education Technology, 10(2):1-8.

Siew, N. M., Amir, N., \& Chong, C. L. (2015). The perceptions of pre-service and in-service teachers regarding a projectbased STEM approach to teaching science. SpringerPlus, 4(1), 1-20.

Sing, T. K. R., \& Chan, S. (2014). Teacher readiness on ICT integration in teaching-learning: A Malaysian case study. International Journal of Asian Social Science., 4(7), 874-885. 
Sumintono, B. (2015). Science education in Malaysia: Challenges in the 21st century. Yogjakarta: Paper presented at 1st International Seminar on Science at Universitas Negeri Yogjakarta.

Unting, J. G., \& Yamat, H. (2017). Dual language Programme (DLP): Teachers' voice. In Proceedings of 73rd ISERD international conference (pp. 20-24). Bali.

Wing, J. M. (2006). Computational thinking. Communication ACM., 49(3), 33-35.

Yadav, A., Stephenson, C., \& Hong, H. (2017). Computational thinking for teacher education. Communications of the ACM, 60(4), 55-62.

Yunus, M. M., \& Sukri, S. I. A. (2017). The use of English in teaching mathematics and science: The PPSMI policy Vis-á-Vis the DLP. Advances in Language and Literacy Studies., 8(1), 133-142.

Submit your manuscript to a SpringerOpen ${ }^{\circ}$ journal and benefit from:

- Convenient online submission

- Rigorous peer review

Open access: articles freely available online

- High visibility within the field

- Retaining the copyright to your article

Submit your next manuscript at $\gg$ springeropen.com 